\title{
INTEGRASI TEKNOLOGI KE DALAM KURIKULUM
}

\section{Suprayekti}

\begin{abstract}
Facilitating instruction and performance improvement in instruction technology become the objectives of instruction technology to solve learning problems faced by the students. This problem can solved and the objectives can be achieved if the technological resources integrated into the curriculum are used properly. How it is done is to be discussed in this article in detail. The teacher as a curriculum developer should possesses technological competence and knows to choose and use the technology integrated in instruction.
\end{abstract}

Key words: ilntegration, technology, curriculum, instruction

\section{Abstrak}

Fasilitasi pembelajaran dan peningkatan kinerja di dalam teknologi pembelajaran merupakan tujuan yang akan dicapai oleh teknolog pembelajaran dalam mengatasi masalah belajar peserta didik. Tujuan ini dapat tercapai dengan menggunakan sumber daya teknologi yang diintegrasikan ke dalam kurikulum. Pembelajar dalam hal ini guru sebagai pengembang kurikulum harus memiliki sejumlah kompetensi tentang teknologi. Guru harus memiliki pengetahuan tentang teknologi khususnya dalam pemilihan teknologi dan pemanfaatannya secara terintegrasi di dalam pembelajaran.

Kata-kata kunci: integrasi, teknologi, kurikulum, peristiwa pembelajaran

\section{PENDAHULUAN}

Kurikulum merupakan pedoman dalam menentukan arah untuk mencapai tujuan pendidikan di tiap satuan pendidikan telah disusun oleh masingmasing satu pendidikan yang dikenal dengan Kurikulum Tingkat Satuan Pendidikan (KTSP). KTSP dikembangkan mengacu pada standar nasional pendidikan untuk mencapai tujuan pendidikan nasional dengan dilandaskan kepada Undang-Undang Nomor 20 Tahun 2003 Pasal 30 ayat 2, Peraturan Pemerintah Nomor 19 Tahun 2005 Pasal 17 ayat 1, Peraturan Menteri Pendidikan Nasional Nomor 22 dan 23 tahun 2006. Landasan yuridis pengembangan KTSP ini ditunjang dengan prinsip-prinsip pengembangan KTSP diantaranya tanggap terhadap perkembangan, ilmu pengetahuan, teknologi dan seni. Oleh karena itu, semangat dan isi kurikulum harus memberikan pengalaman belajar siswa dengan mengikuti dan memanfaatkan perkembangan ilmu pengetahuan, teknologi, dan seni.

Teknologi sebagai salah satu aspek upaya meningkatkan proses belajar internal siswa, harus diintegrasikan ke dalam implementasi hukum untuk meningkatkan kualitas pembelajaran dan mengurangi peran guru sebagai satu-satunya sumber belajar. Upaya pemberdayaan teknologi ini harus dimiliki oleh guru sesuai dengan Undang-Undang Nomor 14 TAhun 2005 Pasal 8 sebagai kompetensi profesional yaitu kemampuan teknologi yang relevan secara profesional dan prosedural dengan mata pelajaran yang diampu di sekolah. Dengan demikian, guru harus mampu mengintegrasikan teknologi di dalam kurikulum mikro sehingga belajar dan pembelajaran menjadi optimal serta meningkatkan efektivitas dan efisien proses pembelajaran di satuan pendidikannya.

Berdasarkan paparan di atas, rumusan masalahnya adalah "Bagaimana guru dapat mengintegrasikan teknologi ke dalam sebuah kurikulum di sekolah?"

\section{KAJIAN PUSTAKA}

Pengintegrasian teknologi oleh guru ke dalam kurikulum sekolah, dapat dilakukan oleh guru dengan menganalisis konsep integrasi teknologi, kompetensi guru bidang teknologi, prosedur pengintegrasian teknologi ke dalam kurikulum, dan penerapan integrasi teknologi.

Integrasi Teknologi

Konsep integrasi teknologi dapat dilihat dari dua istilah, yaitu integrasi dan teknologi. Kata integrasi berasal dari bahasa Inggris "integration" yang artinya pengintegrasian atau penggabungan. Menurut kamus Bahasa Indonesia, kata integrasi artinya penyatuan (hingga menjadi utuh). Sedangkan teknologi berasal dari bahasa Yunani 'techne" yang artinya cara dan "logos" yang artinya pengetahuan, dan dapat diartikan sebagai pengetahuan tentang 
cara. Dengan melihat arti kedua kata tersebut, maka integrasi teknologi berarti penyatuan, penggabungan tentang pengetahuan cara.

Heinich, Molenda dan Russell (1993) yang dikutip oleh Prawiradilaga \& Siregar (2004) mengatakan bahwa teknologi sebagai suatu pengetahuan diterapkan oleh manusia untuk mengatasi masalah dan melaksanakan tugas dengan cara sistematis dan ilmiah, terdiri dari teknologi perangkat keras dan lunak. Arti teknologi ini sejalan dengan definisi teknologi pendidikan yang dikemukakan oleh AECT (2004), di mana di dalam definisi tersebut kata teknologi mengandung makna alat dan metode atau proses dan sumber yang digunakan secara tepat guna sesuai situasi pembelajaran. Berdasarkan kedua pandangan ini, maka integrasi teknologi menjadi lebih luas, yaitu integrasi dalam memfasilitasi berlangsungnya proses belajar dan meningkatkan kinerja guru dalam membelajarkan siswa. Jika divisualisasikan integrasi teknologi dalam sistem pembelajaran, maka teknologi merupakan komponen sistem pembelajaran.

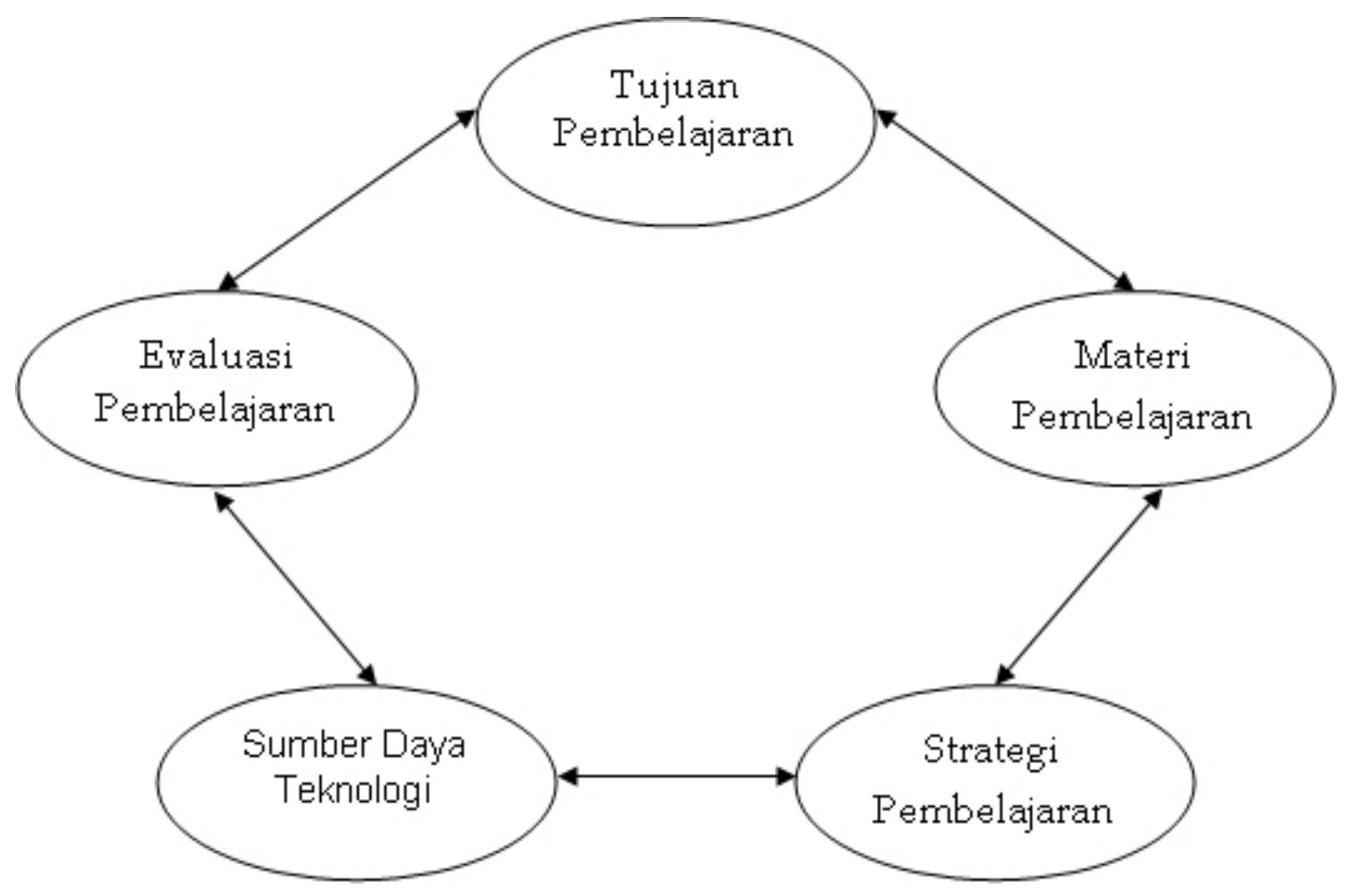

Gambar 1. Pembelajaran yang Mengintegrasikan Teknologi

Integrasi teknologi ke dalam pembelajaran atau sebuah kurikulum di sekolah menurut Roblyer, Edwards dan Havriluk (1997:28-29) dikarenakan teknologi digunakan di berbagai situasi seperti sistem pendidikan (sekolah dan kelas), dan teknologi (komputer dan teknologi lainnya) dapat membantu efektivitas pembelajaran. Hal ini dikemukakan dengan menekankan kegunaan teknologi dalam pendidikan, yaitu.

a. Meningkatkan motivasi dalam belajar.

b. Meningkatkan kapabilitas pembelajaran yang bersifat khusus.

c. Menunjang pendekatan pembelajaran yang baru/ inovatif.

d. Menambah produktivitas kerja guru.

Teknologi yang dapat diintegrasikan ke dalam kurikulum atau pembelajaran menurut Seels dan
Richey (1994) terdiri dari teknologi cetak, teknologi audiovisual, teknologi berbasis komputer, dan teknologi yang terintegrasi dengan menggabungkan berbagai sarana pendukung sistem belajar, antara isi dan reaksi siswa dalam belajar. Sedangkan Muijs dan Reynolds (2008) membatasi teknologi kepada teknologi informasi dan komunikasi dengan menggunakan berbagai sarana pendukungnya, yaitu perangkat keras komputer, multimedia proyektor, perangkat lunak (program software), dan web atau internet.

Berdasarkan paparan di atas, integrasi teknologi yang dimaksudkan adalah teknologi yang digabungkan untuk menyajikan informasi (isi pelajaran), mengakses informasi, menyelesaikan tugas-tugas rutin, membantu interaktivitas langsung (umpan balik langsung) dan membantu berbagai pengalaman belajar siswa baik di sekolah maupun di luar sekolah. 


\section{Kompetensi Guru Bidang Teknologi}

Integrasi teknologi dalam implementasi kurikulum dapat meningkatkan daya guna dari strategi pembelajaran yang akan digunakan, misalnya strategi e-learning, proses belajar dan membelajarkan akan menggunakan teknologi tinggi, seperti komputer, LCD, CD, dan web. Dalam konteks ini, siswa akan lebih mudah mempelajari isi/materi pelajaran dan melaksanakan kegiatan pembelajaran sesuai dengan tujuan pembelajaran/ kompetensi yang telah ditetapkan. Sedangkan guru harus memfasilitasi belajar siswa dengan mengintegrasikan teknologi untuk memperbaiki kinerja siswa.

Pengintegrasian teknologi ini secara optimal memerlukan kompetensi tertentu yang harus dimiliki oleh guru. Menurut Stakenas, Tishkin dan Resnick (1992) ada lima kompetensi yang harus dimiliki oleh guru yaitu:

1. Pengetahuan dasar tentang teknologi komputer, seperti cara kerja komputer dan penggunaannya dengan mempertimbangkan faktor-faktor sosial, ekonomi, serta pengaruhnya di masyarakat.

2. Keterampilan mengoperasikan peralatan komputer yang dapat menunjang pembelajarannya, misalnya memformat pesan, mencetak dokumen, menggunakan berbagai peralatan pendukung lainnya seperti LCD.

3. Keterampilan menggunakan saran-saran produktivitas (program aplikasi) seperti world processing, data base, spreadsheet, graphics, dan desktop.

4. Keterampilan menggunakan aplikasi perangkat lunak di dalam pembelajaran. Misalnya guru harus dapat menggambarkan model aplikasi perangkat lunak komputer dengan model pembelajaran multimedia, antara latihan dan praktik, tutorial, simulasi, dan permainan. Dalam hal ini, guru harus mampu menilai program aplikasi apa saja yang tepat untuk menunjang proses pembelajaran yang dilakukannya.

5. Keterampilan mengelola aplikasi. Guru harus mengelola komputer untuk menunjang kegiatan pembelajaran atau manajemen pembelajaran, seperti laporan kemajuan siswa, membuat lembar kerja, berkirim surat kepada orang tua. Dengan demikian, guru mampu memahami jaringan komputer.

Kelima kompetensi ini merupakan bekal guru untuk dapat mengintegrasikan teknologi khususnya teknologi berbasis komputer ke dalam perancangan atau pelaksanaan kurikulum di sebuah sekolah. Dengan demikian, keahlian menggunakan teknologi berbasis komputer harus dipelajari oleh guru dalam bentuk pemberian pendidikan dan pelatihan di luar jadwal sekolah.

SedangkanSmaldino, dkk (2008) mengemukakan perancangan integrasi teknologi dengan model ASSURE. Perancangan model ini oleh guru dapat mempermudah pelaksanaan pembelajaran dari kurikulum yang telah dikembangkannya. Guru harus memahami model ASSURE agar pembelajaran dapat dilaksanakan secara sistematis, melalui langkahlangkah di bawah ini.

1. Menganalisis Pemelajar (A: Analyze Learner)

Tiga faktor yang harus dilakukan dalam analisis pemelajar yaitu karakteristik umum, kompetensi dasar spesifik, dan gaya belajar. Karakteristik umum mencakup usia, gender, kelas, budaya atau sosio ekonomi. Kompetensi dasar spesifik meliputi pengetahuan dan keterampilan prasyarat, target, dan sikap. Sedangkan gaya belajar meliputi kecerdasan jamak, preferensi dan kekuatan perseptual, kebiasaan memproses informasi, motivasi, serta faktor-faktor fisiologis.

2. Menyatakan Standar dan Tujuan (S: State of Objective)

Perumusan standar dan tujuan pembelajaran untuk mata pelajaran dapat bersumber dari standar kurikulum nasional, sehingga relevan dan konsisten. Perumusan tujuan pembelajaran yang baik mengandung unsur ABCD (Audience, Behaviour, Condition, dan Degree). Rumusan tujuan pembelajaran membantu guru dalam memilih strategi, teknologi, dan media serta dapat menjadi dasar untuk penilaian dan dasar untuk ekspetasi belajar siswa.

3. Memilih strategi, teknologi, media dan materi (S: Select Methods, Media, and Materials)

Penilaian strategi pembelajaran yang berpusat pada siswa akan melibatkan kegiatan belajarnya secara aktif misal menyajikan sebuah konsep melalui pencarian internet. Sedangkan guru memfasilitasi pembelajaran melalui bimbingan belajar.

Sedangkan pemilikan teknologi media dapat menggunakan kriteria subjek seleksi. Kriteria tersebut adalah selaras dengan standar, hasil dan tujuan, informasi yang terbaru dan akurat, bahasa yang sesuai usia, tingkat ketertarikan dan keterlibatan, kualitas teknis, mudah digunakan, bebas bias, panduan pengguna dan arahan pengguna, merangsang kreativitas, memacu kolaborasi, praktik, dan umpan balik.

Setelah strategi, teknologi dan media yang diperlukan telah dipilih, langkah selanjutnyamemilih materi yang mendukung pelaksanaan strategi, 
teknologi, dan media untuk mata pelajaran yang diampu oleh guru.

4. Menggunakan Teknologi, Media, dan Materi (U: Utilize Media and Materials)

Penggunaan teknologi, media, dan materi yang telah dipilih untuk mata pelajaran yang diampu oleh guru, akan melibatkan " $5 \mathrm{P}^{\prime}$ yaitu preview (meninjau teknologi, media, dan materi), prepare (menyajikan teknologi, media, dan materi), prepare (menyiapkan lingkungan belajar), prepare ( menyiapkan peserta didik), dan provide (menyediakan pengalaman belajar siswa).

5. Mengharuskan partisipasi pemelajar (R: Require Learner Participation)

Partisipasi siswa dimaksudkan untuk meningkatkan kinerja dirancnag pada komponen kegiatan pembelajaran dari kurikulum yang telah dikembangkan oleh guru. Partisipasi siswa dengan memanfaatkan teknologi dapat digunakan untuk latihan, sebagai perkakas (piranti produktifitas), perangkat komunikasi (berkolaborasi dengan teman), dan perangkat penyelesaian masalah serta pengambilan keputusan.

6. Mengevaluasi dan Merevisi (E: Evaluate and Revise)

Evaluasi dan revisi sangat penting bagi pembelajaran yang berkualitas. Pada langkah ini, guru harus menilai hasil belajar peserta didik sesuai dengan tujuan pembelajaranyang telah dirumuskan, misalnya portofolio online. Sedangkan penilaian strategi, teknologi, dan media yang digunakan dalam proses pembelajaran dapat dilakukan oleh guru yang bersangkutan dan masukan dari peserta didik. Berdasarkan hasil evaluasi tersebut, ditindaklanjuti untuk revisi (perbaikan) dari strategi, teknologi, media, dan materi.

Enam langkah dari model ASSURE yang diterapkan dalam pembelajaran terintegrasi dengan teknologi, dapat membantu pengalaman belajar siswa secara optimal. Melalui teknologi, siswa dapat belajar secara mandiri, menyajikan informasi dalam cara yang baru, bekerja secara kolaboratif dengan siswa lain, dan lain-lain.

Model ASSURE sebagai salah satu perancangan integrasi teknologi harus dimiliki oleh guru sebagai kompetensi mengelola pembelajaran berbasis teknologi. Diharapkan guru dapat memanfaatkan teknologi secara sistematis.

\section{Prosedur Pengintegrasian Teknologi}

Pengintegrasian teknologi ke dalam kurikulum dapat dilakukan oleh guru dengan mengawali kegiatan dan mempertimbangkan pemilihan teknologi yang tepat. Menurut Bates (2008), memilih teknologi yang akan digunakan untuk menyampaikan isi pelajaran atau mengelola program pembelajaran dapat menggunakan kriteria ACTION, yaitu.

a. Access

Kemudahan akses menjadi pertimbangan pertama dalam memilih teknologi. Apakah teknologi yang kita perlukan tersedia mudah dan dimanfaatkan oleh siswa? Apakah ada saluran untuk koneksi ke internet, jika siswa membutuhkan materi pelajaran yang relevan dengan mata pelajaran yang sedang ditempuh? Akses juga menyangkut kebijakan dari manajemen sekolah.

b. Cost

Biaya juga menjadi pertimbangan, karena semakin banyak yang menggunakan teknologi maka tingkat keefektifan biaya menjadi sebanding dengan manfaat yang dapat diperoleh.

c. Teaching Functions

Teknologi yang dipilih harus mendukung kegiatan pembelajaran. Apakah untuk pembelajaran berbasis web, apakah untuk melakukan evaluasi atau mempresentasikan pembelajaran dengan memanfaatkan multimedia dan komputer.

\section{d. Interactivity / Interaction/User Friendliness}

Teknologi yang baik adalah yang dapat memunculkan proses interaksi yang intensif antara siswa dengan sumber belajar lainnya. Melalui kriteria ini, maka teknologi yang dipilih adalah yang sesuai dengan tujuan atau kompetensi yang diperlukan oleh penggunanya (user).

e. Organizational Issues

Dukungan organisasi untuk menubagh pembela-jaran inovatif yang berbasis teknologi menjadi pertimbangan untuk keberhasilan penggunaan teknologi yang terintegrasi. Misalnya dengan melakukan perubahan struktural organisasi lembaga dan membangun infrastruktur yang sesuai dengan teknologi yang dipilih.

f. Novelty

Kebaruan teknologi yang dipilih harus menjadi pertimbangan dalam membantu siswa agar mudah memperbaharui isi/materi pelajaran atau substansi yang baru.

g. Speed

Teknologi yang dipilih harus menjadi bagian integral dari proses belajar dan aktivitas belajar siswa, oleh karena itu harus dipertimbangkan seberapa cepat siswa dapat mempelajari materi program pembelajaran?

Kriteria pemilihan teknologi dengan konsep ACTION dapat memberikan pertimbangan dalam mengimplementasikan prosedur mengintegrasikan 
teknologi ke dalam kurikulum. Prosedur yang dapat dilakukan guru menurut Robyler, Adwards dan Havriluk (1997:258), yaitu.

a. Guru mengakses sumber-sumber teknologi yang tersedia di sekolah atau pusat-pusat teknologi di lingkungan sekitarnya dan peralatan yang memadai untuk mengakses teknologi tersebut sehingga dapat diintegrasikan ke dalam alur proses belajar dan pembelajaran.

b. Menghubungkan atau mengaitkan antara kebutuhan belajar siswa dengan sumber-sumber yang tersedia sesuai dengan kurikulum atau rencana pelajaran yang telah dikembangkan.

c. Merencanakan kegiatan belajar siswa melalui pemanfaatan teknologi ke dalam proses pembelajaran, apakah hanya dibutuhkan satu konten disiplin ilmu atau berbagai disiplin ilmu lainnya.

d. Menata peralatan yang akan digunakan selama proses pembelajaran berlangsung, sebelum siswa hadir di kelas.

e. Melakukan uji coba pemanfaatan teknologi dengan melibatkan peserta didik.

f. Menilai dan merevisi penggunaan teknologi yang diujicobakan. Evaluasi dan revisi ini untuk melihat kinerja teknologi akan terus dilanjutkan, maka revisi digunakan untuk menyempurnakan Pengintegrasian teknologi ke dalam kurikulum.

Prosedur mengintegrasikan teknologi ke dalam kuriikulum dari suatu disiplin ilmu atau proses pembelajaran, akan mengoptimalkan kualitas integrasi teknologi secara tepat guna.

\section{HASIL DAN PEMBAHASAN}

\section{Penerapan Integrasi Teknologi}

Proses Pengintegrasian teknologi ke dalam kurikulum, dapat digunakan dalam implementasi kurikulum, yaitu pada proses pembelajaran atau dikaitkan ke dalam suatu disiplin ilmu. Pembelajaran sebagai seperangkat tindakan yang dirancang sengaja oleh guru merupakan peristiwa eksternal untuk menunjang proses belajar internal siswa. Gagne (1985) mendefinisikan pembelajaran sebagai situasi eksternal yang harus dirancang sedemikian rupa untuk mengaktifkan, mendukung, dan mempertahankan proses internal yang terdapat dalam setiap peristiwa belajar.Peristiwa belajar oleh Gagne(1977) dikemukakan ada sembilan dan dapat diintegrasikan dengan teknologi seperti dikemukakan oleh Shambaugh dan Magliro (2006:1996). Berbagai alternatif dapat dilakukan guru dengan mengintegrasikan teknologi pada peristiwa pembelajaran, antara lain:
Tabel 1. Integrasi Teknologi dengan Peristiwa Pembelajaran

\begin{tabular}{|c|c|}
\hline Peristiwa Pembelajaran & Teknologi \\
\hline 1. Menarik perhatian & $\begin{array}{l}\text { Peragaan/ } \\
\text { demonstrasi }\end{array}$ \\
\hline $\begin{array}{l}\text { 2. Menyampaikan } \\
\text { tujuan pembelajaran }\end{array}$ & $\begin{array}{l}\text { Bahan presentasi, } \\
\text { handout, ditulis pada } \\
\text { papan tulis atau lisan. }\end{array}$ \\
\hline $\begin{array}{l}\text { 3. Mengingatkan } \\
\text { konsep/prinsip yang } \\
\text { telah dipelajari }\end{array}$ & $\begin{array}{l}\text { Ringkasan pokok } \\
\text { materi melalui bahan } \\
\text { presentasi }\end{array}$ \\
\hline $\begin{array}{l}\text { 4. Menyampaikan } \\
\text { materi pelajaran }\end{array}$ & $\begin{array}{l}\text { Teknologi bahan } \\
\text { presentasi, } \\
\text { multimedia, simulasi } \\
\text { dan internet. }\end{array}$ \\
\hline $\begin{array}{l}\text { 5. Memberikan } \\
\text { bimbingan dan } \\
\text { belajar }\end{array}$ & $\begin{array}{l}\text { Teknologi: kegiatan } \\
\text { online dengan guru. }\end{array}$ \\
\hline 6. Memperoleh kinerja & $\begin{array}{l}\text { Kinerja siswa melalui } \\
e \text {-mail atau web. }\end{array}$ \\
\hline 7. Memberikan balikan & $\begin{array}{l}\text { Ketepatan kinerja } \\
\text { siswa dikomentari } \\
\text { melalui e-mail atau } \\
\text { web }\end{array}$ \\
\hline 8. Menilai hasil belajar & $\begin{array}{l}\text { Menilai dengan } \\
\text { program computer } \\
\text { adaptive test secara } \\
\text { online atau offline / } \\
\text { CD. }\end{array}$ \\
\hline $\begin{array}{l}\text { 9. Memperkuat retensi } \\
\text { dan transfer belajar }\end{array}$ & $\begin{array}{l}\text { Mengulang bagian- } \\
\text { bagian pelajaran } \\
\text { secara berurutan dan } \\
\text { ditambah contoh- } \\
\text { contoh. }\end{array}$ \\
\hline
\end{tabular}

Berdasarkan sembilan jenis teknologi di atas, pembelajaran dapat dilaksanakan secara langsung di kelas atau melalui e-learning.

Penerapan lain dari integrasi teknologi adalah dengan disiplin ilmu yang dipelajari oleh siswa. Pengintegrasian teknologi ini sumber daya yang akan digunakan juga dipilih oleh guru. Sebagai contoh dikemukakan oleh Robyler, Edwards dan Havriluk (1997:261-305) sebagai berikut:

1. Pengintegrasian teknologi ke dalam mata pelajaran seni musik

a. Siswa diminta untuk mengaransemen ulang sebuah lagu dengan software khusus yaitu MIDI (The Musical Instrument Digital), Synthesizer dan jaringan MIDI.

b. Siswa diminta untuk membuat sebuah lagu dengan menggunakan program pembelajaran aplikasi musik seperti Play it By Ear, Piano Works.

c. Siswa diminta untuk mempraktikkan konser mini di kelas, maka terlebih dahulu diminta untuk mempelajari video aksi panggung 
seorang konduktor dari CD pembelajaran musik atau video klip musik.

d. Siswa diminta untuk mempraktikkan konser mini di kelas, maka terlebih dahulu diminta untuk mempelajari video aksi panggung seorang konduktor dari CD pembelajaran musik atau video klip musik.

2. Pengintegrasian teknologi ke dalam mata pelajaran bahasa asing

Integrasi teknologi ke dalam mata pelajaran bahasa asing dimaksudkan untuk memfasilitasi kemampuan menulis, mendengar, berbicara, dan membaca. Misalnya game untuk pengolahan kata atau tebak kata yaitu aplikasi French Micro Scrabble. Contoh lainnya adalah program aplikasi materi grammar, internet dengan situs www.willamatte,edu atau video yang hanya membutuhkan video player dan monitor televisi.

3. Pengintegrasian teknologi ke dalam disiplin ilmu lainnya

a. Teknologi dalam kurikulum ilmu sosial seperti teknologi dengan model simulasi untuk menemukan bukti-bukti peninggalan sejarah.

b. Teknologi dalam kurikulum ilmu matematika dan pengetahuan alam, seperti aplikasi perangkat lunak matematika atau paket personal science laboratory.

c. Teknologi dalam kurikulum siswa berkebutuhan khusus, misalnya komputer dengan huruf Braille atau komputer bicara yang dilengkapi dengan berbagai perangkat lunak dan variasi keyboard, atau telekomunikasi untuk siswa yang mengalami gangguan fisik dapat dirancang special education web page.

Penerapan integrasi teknologi dari aspek pembelajaran dan disiplin ilmu di atas, dapat dikatakan sebagai langkah strategi dalam meningkatkan kualitas belajar dan pembelajaran.

\section{PENUTUP}

Berdasarkan rumusan masalah dan pembahasan yang telah dipaparkan di muka, maka dapat disimpulkan.

Pertama, pengintegrasian teknologi di dalam kurikulum, dapat mengatasi berbagai masalah belajar yang timbul baik di dalam pembelajaran langsung maupun tidak langsung.

Kedua, pengintegrasian teknologi di dalam kurikulum merupakan langkah strategis dalam membantu proses belajar internal siswa dan meningkatkan kualitas belajar dan pembelajaran, baik melalui teknologi perangkat keras maupun perangkat lunak.

Ketiga, keberhasilan mengintegrasikan teknologi dalam kurikulum oleh guru, dipengaruhi oleh dua faktor yaitu kompetensi guru terhadap penguasaan/ pemahaman teknologi komputer, keterampilan dalam menggunakan komputer dan sumber daya pendukungnya serta faktor kriteria dalam memilih teknologi yang sesuai dengan tujuan pembelajaran/ kompetensi yang telah ditetapkan.

Keempat, pemanfaatan teknologi di dalam pembelajaran, dirancang oleh guru dengan model ASSURE. Sehingga pengalaman belajar peserta didik dapat terlaksana dengan efektif dan efisien.

\section{DAFTAR PUSTAKA}

Bates, A.W. (2008). Technology, open learning and distance education. London: Routledge.

Gagne, R.M. (1985). The condition oflearning. New York: Holt, Rinehart and Winston.

Miarso, Y. (2004). Menyemai benih teknologi pendidikan. Jakarta: Kencana.

Muijs, D. \& Reynolds, D. (2008). Effective teaching: Evidence and practice. London: Sage Publication. Ltd.

Prawiradilaga, D.S. \& Siregar, E. (2004). Mozaik teknologi pendidikan. Jakarta: Kencana.

Roblyer, M.D, Jack, E. \& Anne, H.M. (1997). Integrating educational technology into teaching. New Jersey: Prentice-Hall, Inc.

Rusman. (2009). Manajemen kurikulum. Jakarta: Rajawali Pers.

Shambaugh, N. \& Magliaro, S.G. (2006). Instructional design: A systematic approach for reflective practice. New York. Pearson Education, Inc.

Smaldino, S.E., Lowther, D.L., \& Russell, J.D. (2008). Instructional technology and media for learning (Terjemahan). Jakarta: Rencana Prenada Media

\section{KETERANGAN PENULIS}

Suprayekti, dilahirkan di Jakarta pada tanggal 14 Oktober 1960. Saat ini menjabat sebagai dosen di Jurusan Kurikulum dan Teknologi Pendidikan Universitas Negeri Jakarta 


\section{PETUNJUK PENULISAN}

\section{Keaslian Naskah}

Tulisan yang dikirimkan kepada editor harus merupakan tulisan yang orisinal dan bukan tulisan yang sedang dipertimbangkan untuk dimuat di media, jurnal, atau majalah lain baik nasional maupun internasional. Penulis harus dapat menjamin bahwa naskah yang diajukan untuk diterbitkan tidak mengandung unsur plagiarisme atau pelanggaran etika akademik lainnya. Setiap pelanggaran sepenuhnya menjadi tanggung jawab penulis.

\section{Ragam Naskah}

Naskah yang dikirim dapat berupa hasil studi literatur, studi empiris, studi kasus, evaluation research dan studi kebijakan, analisis deskriptif, opini, referensi mata kuliah, isu-isu mutakhir pendidikan, atau resensi buku.

\section{Bahasa dan Format Penulisan}

Naskah dapat ditulis dengan menggunakan bahasa Indonesia maupun bahasa Inggris. Khusus abstrak ditulis dalam bahasa Inggris (75-150 kata). Judul dan Abstract dimuat pada halaman pertama. Panjang tulisan diusahakan tidak lebih (maksimal) dari $7.500 \mathrm{kata}$, atau sekitar 20 halaman, tidak termasuk kuesioner dan lampiran lainnya. Semua naskah ditulis dengan jenis huruf Book Antiqua, 10 point dalam satu setengah spasi, ukuran A4. Biografi penulis, alamat dan nomor telepon harus pula disertakan pada halaman tersendiri. Tiap referensi harus memuat biografi secara rinci dan judul tidak boleh disingkat. Cara pencantuman bibliografi mengadopsi sistem APA (American Psychological Association). Contohnya sebagai berikut:

Adrian, (2004). Metode mengajar berdasarkan tipologi belajar siswa. 20 Oktober 2004, dari http:www// perspektif/artikel/unj.ac.id

Ahmad, N. (2002). Etika dan moral menurut Al-Ghazali. Dikdatika Islamika. Vol. 3 Nomor 8.

Dewey, J. (1961). Democracy and education. New York: McMillan.

Moleong, L. J. (1998). Proposal penelitian kualitatif. Jakarta: Program Pascasarjana IKIP Jakarta. (Tidak diterbitkan).

Zainu, M. (2002). Solusi pendidikan anak masa kini. ( Syarif Hade, penterjemah). Jakarta: Mustaqiim.

\section{Metode Review}

Naskah yang telah dinyatakan lolos dari seleksi pendahuluan akan dikirimkan kepada satu atau dua blind reviewer (reviewer tidak tahu nama penulis dan sebaliknya). Penulis berkewajiban melakukan revisi (bila ada) sebagai syarat untuk dipublikasikannya sebuah artikel.

\section{Bagan, Diagram, Gambar dan Tabel.}

Bagan, diagram dan gambar diberi nomor urut berdasarkan angka arab, dengan diberi judul singkat menggunakan huruf kapital serta diberi nama mendatar. Teks penamaan (caption) harus jelas dan sesuai dengan yang diperlihatkan pada gambar dan tiap gambar harus disajikan pada kertas terpisah dan dapat direproduksi. Tabel harus diberi nomor urut dengan menggunakan angka arab dan deskriptif judul tabel dibuat sesingkat mungkin serta diberi nama ke bawah dan ke samping.

\section{Penyerahan Naskah.}

Editor hanya menerima dan mempertimbangkan naskah yang memenuhi syarat seperti yang tertera di atas. Naskah diserahkan berupa 2 (dua) hard copy dan 1 (satu) soft copy naskah dalam bentuk file atau disket dan dikirimkan ke Redaksi Jurnal Perspektif Ilmu Pendidikan FIP UNJ dengan alamat Kampus A UNJ Gd. Daksinapati, Jl. Rawamangun Muka, Jakarta Timur, 13220. E-mail: visi_ptk_pnf@yahoo.co.id. Penulis tidak dikenakan biaya submisi dan Redaksi tidak berkewajiban untuk mengembalikan kepada penulis naskah yang tidak dimuat. 